\title{
Physiological Responses to Endurance Work Performance in Relation to Altitude
}

\author{
Rikshesh MALHOTRA ${ }^{1)}$, \\ Vijinder BHALLA ${ }^{2)}$ and \\ Naresh WOHERRA ${ }^{2)}$ \\ 1) Anthropological Survey of India, Port Blair-744101 INDIA \\ 2) Department of Anthropology, Panjab University, \\ Chandigarh-160014 INDIA
}

\begin{abstract}
A study of work capacity and physiological responses to endurance work performance was carried out at plains (Chandigarh $750 \mathrm{ft}$. above sea level) and at higher altitude (Sainj, India $4500 \mathrm{ft}$. above sea level). Investigations were carried out on members of a field party consisting of 8 individuals ( 4 males and 4 females) in the age group of 20-25 years. The team members were first examined soon after their arrival at Sainj. The second reading was taken after a stay of about 14-15 days in Sainj, and the third reading was taken after about a month of their return to plains.

The study revealed that cardio-respiratory characteristics are closely related to altitudinal exposure. The principal adaptive responses to hypoxic conditions at higher altitude consisted of increase in pulse rate and decrease in oral temperature and blood pressure (both systolic and diastolic). Vital capacity did not show any adaptive response to altitude at least up to 4500 $\mathrm{ft}$. above sea level. Increase in physical work capacity was observed at higher altitude. Physiological responses to endurance work performance at plains and at higher elevations revealed marked differences.
\end{abstract}

\section{INTRODUCTION}

It is a well known fact that altitude exposure impairs physical abilities and has been confirmed by many workers like JOKL \& JOKL (1968), GODDARD et al. (1967) and MARGARIA (1967). The maximal work capacity of the new comers decreases, and sub-maximal work becomes far more stressful resulting in high heart rate and rapid breathing and thereby decreasing the endurance time. Also studies on physiology of exercise have shown that endurance is a changeable characteristic and is subject to improvement or reduction under varied environmental conditions. In the present report an attempt is made to examine the exercise endurance in relation to altitude.

\section{MATERIAL AND METHOD}

The study of work capacity and physiological responses to endurance work performance was carried out on a team of sojourners consisting of 8 members, 4 males and 4 females in the age group of 20 to 25 years. The members who are lowlanders were examined for a set of cardio-respiratory characters at different intervals of time described here as stage I, II and III. Stage I refers to first examination carried out at altitude of 4500 ft. above sea level (Sainj, Distt. Kulu, Himachal Pradesh, India), soon after the team arrived there. Stage II refers to second examination carried out after an interval of 14-15 days at the same altitude and stage III 
refers to 3rd examination carried out after about a month's stay at plains (Chandigarh, altitude around $750 \mathrm{ft}$. above sea level) on return from higher altitudes. Work capacity was tested by standard Harvard step test and was measured in terms of Rapid Fitness Index (R. F. I.).

The Physiological parameters examined included pulse rate, oral temperature, blood pressure and vital capacity. Two sets of readings were noted, one before exercise and the other after exercise. The subjects were made to rest for 1 to 2 minute after exercise before the readings were recorded.

Rapid Fitness Index was calculated according to formula given in the IBP publication No. 9 (WEINER \& LoWRIE, 1969) which is:

\section{R.F.I. $=\frac{\text { Duration of exercise } \times 100}{\text { Pulse rate after } 1 \text { to } 11 / 2 \min \times 5.5}$}

\section{OBSERVATIONS}

Following are the salient observations made in respect to work capacity and other parameters examined.

R.F.I. value showed an increase of 7.6 units in males and 4.5 units in females within a span of 15 days stay at higher altitudes $(4500$ ft. above sea level), i.e. I and II stages ( $T a-$ ble 1). The sexual dimorphism in the R.F.I. value is more pronounced at stages II and III where the differences are to the tune of 12.4 and 12.8 units respectively. The effect of the continued adaptation can be seen from $I$ and III stages. Though the R.F.I. value decreases at III stage as compared to the II stage but still the values are higher than those of the I stage.

The differences in the value between various stages for females show that R.F.I. value for them does not change as much as for males and are in WADDINGTON's (1957) terminology: they i.e. females are better 'canalized' or show more power of homeorrhesis.

Only a slight rise was registered in the pulse rate with the gain in altitude in both sexes. The mean pulse rate measured as beats per $1 / 2$ minute was around 40 in mlaes and around 37 in females (Table 2a, 2b). The change in pulse rate is relatively higher in males. The post exercise changes in both

Table 1. Rapid fitness index.

\begin{tabular}{lrrrrrrrr}
\hline & \multicolumn{2}{c}{ Stage I } & & \multicolumn{2}{c}{ Stage II } & & \multicolumn{2}{c}{ Stage III } \\
\cline { 2 - 3 } Male & Female & & Male & Female & & Male & Female \\
\cline { 2 - 3 } Mean & 26.6 & 17.3 & & 34.2 & 21.8 & & 32.2 & 19.4 \\
S.D. & 5.8 & 6.3 & & 8.6 & 4.8 & & 6.2 & 5.7 \\
\hline
\end{tabular}

Table 2. Pulse rate.

Table 2a-Males

\begin{tabular}{|c|c|c|c|c|c|c|}
\hline \multirow{4}{*}{$\begin{array}{l}\text { Mean } \\
\text { S.D. }\end{array}$} & \multirow{2}{*}{\multicolumn{2}{|c|}{ 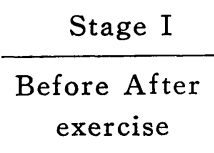 }} & \multicolumn{2}{|c|}{ Stage II } & \multicolumn{2}{|c|}{ Stage III } \\
\hline & & & \multicolumn{2}{|c|}{$\begin{array}{c}\text { Before After } \\
\text { exercise }\end{array}$} & \multicolumn{2}{|c|}{$\begin{array}{c}\text { Before After } \\
\text { exercise }\end{array}$} \\
\hline & 41 & 54 & 42 & 52 & 38 & 52 \\
\hline & 5.2 & 12.7 & 5.1 & 9.5 & 2.6 & 7.6 \\
\hline \multicolumn{7}{|c|}{ Table $2 \mathrm{~b}-$ Females } \\
\hline Mean & 39 & 45 & 37 & 46 & 36 & 49 \\
\hline S.D. & 9.0 & 6.0 & 6.5 & 9.5 & 3.9 & 6.9 \\
\hline
\end{tabular}


sexes are more pronounced in plains than at higher altitudes. The post exercise value remains almost same at all the three stages in males, whereas in females the post exercise value is increasing at all stages and consequently the difference in pre- and post-exercise values is also increasing.
A general fall in oral temperature is observed at higher altitudes (Table $3 a, 3 b$ ). The post exercise results show that the fall in oral temperature in males is more pronounced at higher altitudes $\left(-.55^{\circ} \mathrm{F}\right)$ and in females it is more marked at lower altitudes $\left(-.5^{\circ} \mathrm{F}\right.$ and $-.65^{\circ} \mathrm{F}$ at I and III stage).

Table 3. Oral temperature.

Table $3 a-$ Males

\begin{tabular}{|c|c|c|c|c|c|c|}
\hline \multirow{4}{*}{$\begin{array}{l}\text { Mean } \\
\text { S.D. }\end{array}$} & \multicolumn{2}{|c|}{ Stage I } & \multicolumn{2}{|c|}{ Stage II } & \multicolumn{2}{|c|}{ Stage III } \\
\hline & $\begin{array}{l}\text { Before } \\
\text { exer }\end{array}$ & $\begin{array}{l}\text { After } \\
\text { ise }\end{array}$ & $\begin{array}{l}\text { Before } \\
\text { exer }\end{array}$ & $\begin{array}{l}\text { After } \\
\text { ise }\end{array}$ & $\begin{array}{r}\text { Before } \\
\text { exer }\end{array}$ & $\begin{array}{l}\text { After } \\
\text { cise }\end{array}$ \\
\hline & 98.3 & 97.9 & 98.15 & 97.6 & 98.35 & 98.2 \\
\hline & .65 & .65 & .18 & .28 & .25 & .22 \\
\hline \multicolumn{7}{|c|}{ Table $3 \mathrm{~b}-$ Females } \\
\hline Mean & 97.75 & 97.25 & 97.55 & 97.2 & 98.2 & 97.55 \\
\hline S.D. & .59 & .59 & .72 & .63 & .66 & .79 \\
\hline
\end{tabular}

Table 4a. Systolic blood pressure.

Table $4 \mathrm{a}^{1}$-Males

\begin{tabular}{|c|c|c|c|c|c|c|}
\hline \multirow{5}{*}{$\begin{array}{l}\text { Mean } \\
\text { S.D. }\end{array}$} & \multicolumn{2}{|c|}{ Stage I } & \multicolumn{2}{|c|}{ Stage II } & \multicolumn{2}{|c|}{ Stage III } \\
\hline & Before & After & Before & After & Before & After \\
\hline & \multicolumn{2}{|c|}{ exercice } & \multicolumn{2}{|c|}{ exercise } & \multicolumn{2}{|c|}{ exercise } \\
\hline & 120 & 131 & 118 & 140 & 124 & 151 \\
\hline & 7.6 & 15 & 9.0 & 8.5 & 10.2 & 14.8 \\
\hline \multicolumn{7}{|c|}{ Table $4 a^{2}-$ Females } \\
\hline Mean & 106 & 118 & 105 & 121 & 109 & 116 \\
\hline S. D. & 4.1 & 10.9 & 1.8 & 7.4 & 2.0 & 4.3 \\
\hline
\end{tabular}

Table 4b. Diastolic blood Pressure.

Table $4 b^{1}-$ Males

\begin{tabular}{lcccccc}
\hline & \multicolumn{2}{c}{ Stage I } & \multicolumn{2}{c}{ Stage II } & \multicolumn{2}{c}{ Stage III } \\
\cline { 2 - 7 } & \multicolumn{2}{c}{ Before After } & \multicolumn{2}{c}{ Before After } & \multicolumn{2}{c}{ Before After } \\
exercise & \multicolumn{2}{c}{ exercise } & \multicolumn{2}{c}{ exercise } \\
Mean & 65 & 58 & 69 & 64 & 70 & 67 \\
S.D. & 10.4 & 15.7 & 12.2 & 12.3 & 4.8 & 6.2 \\
\hline Table & $4 b^{2}-$ Females & & & & \\
\hline Mean & 65 & 60 & 65 & 60 & 69 & 66 \\
S.D. & 6.2 & 5.1 & 5.6 & 4.4 & 4.1 & 4.0 \\
\hline
\end{tabular}


The systolic blood pressure registers a decline at higher altitude in both sexes (Table $4 a^{1}$ and $\left.4 a^{2}\right)$ results show that there is a marked rise in blood presseure after exercise. It is interesting to note that where as the rise is more pronounced in males at lower altitudes, i.e. III stage; in females it is more pronounced at higher altitudes, i.e. II stage. It bears an inverse relationship to oral temperature in so far a greater fall in oral temperature is accompanied by a lesser fall in blood pressure and vice-versa. As far as diastolic blood pressure is concerned a general decrease is seen in both the sexes in post exercise phase (Table $4 b^{1}$ and $4 b^{2}$ ). Whereas the pre-exercise values are either constant or increasing in all the three stages for both the sexes, the difference between pre- and post-exercise values keeps on decreasing.

The vital capacity measured as the forced expiratory volume, does not appear to be affected by altitude at least up to the height of around $4500 \mathrm{ft}$. above seal level (Table $5 \mathrm{a}$, $5 b)$. The post exercise value too, does not seem to bear any significant influence on the vital capacity of an individual whether male or female. Only in males marked post exercise increase is seen in the I stage. Further again only males show marked differences between I and III stages and between II and III stages in pre- and post-exercise phases (Table 5c).

\section{DISCUSSION}

A piecemeal analysis of the findings of the present study reveals that the exposure to higher altitudes diminishes the work capacity, oral temperature and cardiac out put(systolic blood pressure) in the initial stages. Acclimatization to higher altitudes is fairly quick and within a span of 15 days the body physiology is readjusted as to resulting in a markedly improved work capacity. Pulmonary ventilation does not respond to lesser variations in barometric pressure as is indicated by little change in vital capacity up to an altitude of $4500 \mathrm{ft}$. above sea level.

VELASQUEZ (1970) states that pulse rate is nearly always lower in higher altitude natives than in sea level subjects. The result of the present report, however, suggest that there is a slight though perhaps not significant rise

Table 5. Vital capacity.

Table 5a-Males

\begin{tabular}{|c|c|c|c|c|c|c|}
\hline \multirow{4}{*}{$\begin{array}{l}\text { Mean } \\
\text { S. D. }\end{array}$} & \multicolumn{2}{|c|}{ Stage I } & \multicolumn{2}{|c|}{ Stage II } & \multicolumn{2}{|c|}{ Stage III } \\
\hline & \multicolumn{2}{|c|}{$\begin{array}{c}\text { Before After } \\
\text { exercise }\end{array}$} & \multicolumn{2}{|c|}{$\begin{array}{c}\text { Before After } \\
\text { exercise }\end{array}$} & \multicolumn{2}{|c|}{$\begin{array}{c}\text { Before After } \\
\text { exercise }\end{array}$} \\
\hline & 3400 & 3588 & 3412 & 3475 & 3562 & 3588 \\
\hline & 408 & 435 & 320 & 350 & 571 & 557 \\
\hline \multicolumn{7}{|c|}{ Table $5 \mathrm{~b}-$ Females } \\
\hline Mean & 2588 & 2575 & $\angle 2475$ & 2527 & 2500 & 2512 \\
\hline S.D. & 440 & 492 & 380 & 395 & 216 & 210 \\
\hline \multicolumn{7}{|c|}{ Table 5c: Stage-wise Differences } \\
\hline & I \& II & Stage & I \& III & Stage & II \& III & Stage \\
\hline & $\begin{array}{r}\text { Before } \\
\text { exer }\end{array}$ & $\begin{array}{l}\text { After } \\
\text { cise }\end{array}$ & $\begin{array}{r}\text { Before } \\
\text { exer }\end{array}$ & $\begin{array}{l}\text { After } \\
\text { cise }\end{array}$ & $\begin{array}{l}\text { Before } \\
\quad \text { exerc }\end{array}$ & $\begin{array}{l}\text { After } \\
\text { cise }\end{array}$ \\
\hline Males & +12 & -113 & +162 & 0 & +150 & +113 \\
\hline Females & -113 & -48 & -88 & -63 & +25 & -15 \\
\hline
\end{tabular}


in pulse rate when the lowlanders are shifted to higher altitudes. The disagreement in the two reports could possibly be due to differences in the acclimatization process at lesser heights from the process that are initiated at high altitudes (ten thousand $\mathrm{ft}$. and above). A noteworthy finding of the present study in the sexual dimorphism in physiological responses to endurance work performance at different altitudes. While the females are characterised by a greater rise in post exercise blood pressure accompanied with a lesser fall in temperature at higher altitudes, it is the other way round in males.

To sum up the acclimatization process at higher altitudes involves significant changes in physiological responses, which are of critical importance to work capacity of an individual. Further the cardiac characters respond more easily to rise in altitude than the respiratory characters. The recovery process, however, is fairly quick and normal levels are attained within a span of about 2 weeks.

\section{REFERENCES}

GODDARD, R.F., B. BALKE and U.C. LUFT (eds.), 1967: The effects of altitude on physical performance. The Athletic Institute, Chicago.

JoKL, E. and P. JoKL (ed.), 1968: Medicine and sport-Vol.-I, Exercise and Altitude. Karger, Basal.

MARGARIA, R.(ed.), 1967: Exercise at altitude. Excerpta Medica Foundation, Amsterdam.

VelasqueZ, T., 1970: Aspects of physical activity in high altitude natives. Amer. J. Phys. Anthropol., 32: 251-258.

WADDINGTON, C.H., 1957: The strategy of genes. A discussion of some theoretical biology. Allen and Unwin, London.

WEINER, J.S. and J.A. LOWRIE, 1969: Human biology-A guide to field methods. Blackwells Ltd, Oxford.

(Received March 8, 1978)

高地での持久性作業における生理的反応

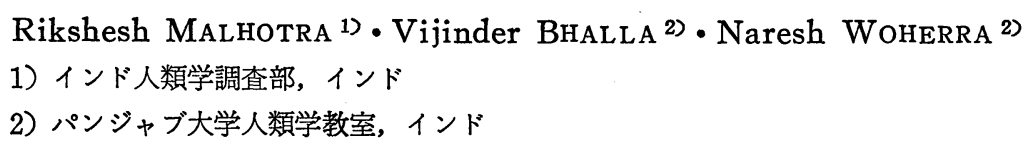

平地（チャンディガール，海抜 750 フィート） と高地（サインジ, インドヒマチャル州クル区, 海抜 4500 フ ヘート) において, 20-25歳の 8 名 (男子 4 名と女子 4 名) 加らなる野外調査隊員について, 持久性作業に打 ける作業能力と生理的反応を研究した。隊員は最初にサインジに着いてすぐ検查され，2度目はサインジ滞在 14一15日後に，3度目は平地に戻って約 1 ケ月後に調べられた。作業能力はハーバードステップテストにおけ る Rapid Fitness Indexにより測定された。呼吸循環機能の測定項目は, 眽拍数, 口腔温, 血圧 (収縮期圧 之弛緩期圧), 肺活量である。

呼吸循環機能は高地曝露之密接に関係した。高地における低酸素に対する主な適応反応は, 脈拍数の増加之 口腔温の低下及び血圧（収縮期圧，弛緩期圧とも）の低下であった。肺活量は少なくとも海抜 4500 フィートま では高地に対する適応的反応を示さなかった。高地滞在での作業能力の増大が観察された。持久性作業におけ る生理的反応は平地と高地とで著しい相違を示した。 